$\mathbb{B}$

J. bio-sci. 22: 101-110, 2014

ISSN 1023-8654

http://www.banglajol.info/index.php/JBS/index

\title{
EFFECTS OF FUNGICIDES AND PLANT EXTRACTS ON SEED GERMINATION AND SEED ASSOCIATED MYCOFLORA OF Lens arietinum L. AND Lathyrus sativus
}

\author{
Mst. Ferdowsi Mahal* \\ Department of Botany,University of Rajshahi, Rajshahi-6205, Bangladesh
}

\begin{abstract}
Contexts: seed treatment reduced seed mycoflora. Evidences revealed that chemical fungicides and plant extracts were effectively controlled seed mycoflora and enhanced seed germination of pulse crops.

Objectives: To determine the effects of chemical fungicides and plant extracts on seed germination and seed associated mycoflora on Lens arietinum L. (lentil) and Lathyrus sativus (khesari).

Materials and Methods: All the samples were collected Rajshahi region during June - August 2012. The detection of seed mycoflora, seed germination and seed treatment with fungicides and plant extracts were carried out by using the blotter test (ISTA-1966).

Results: Seed germination percentage was significantly $(p \leq 0.05)$ increased with both the treatments. Captan (1.2\%) was more effective in comparison with Dithane M-45 (1.4\%) and seed germination (\%) was gradually increased with increase of the doses of fungicides. Seed associated mycoflora also significantly $(p \leq 0.05)$ varied with the treatments. Aspergillus flavus was the most dominant fungi in lentil and Fusarium oxysporum was in khesari for both the treatments and control. No fungi were recorded at 1.2 and1.4\% doses of Captan and Dithane M-45 treated seeds of both pulses. Plant extracts increased germination percentage over control and showed different levels of antifungal activity against seed associated mycoflora (SAM) of both pulse seeds. Among the extracts, Allium sativum showed promising result in controlling of SAM of lentil and khesari. Besides this, A. flavus was remarkably eliminated with the all types of used extracts.

Conclusion: From this study it had been clearly found that seed treatment with chemical fungicides and plant extracts were controlled seed mycoflora of lentil and khesari and increased seed germination.
\end{abstract}

Key words: Pulse seeds, Chemical fungicides, Plant extracts, Blotter test, Seed germination, Seed associated fungi.

\section{Introduction}

Pulses have special significance in the dietary of the vegetarian people as they contain more protein (2 to 3 times) than in cereals. Lentil and Khesari are the most important pulse crops grown especially in dry areas of the Indian subcontinents and Europe. In many developing countries besides important human food and animal feeds, these also play a major role in management of soil fertility particularly in dry lands. Nutritionally they are very rich in protein, carbohydrates, fat and $\mathrm{Ca}, \mathrm{Fe}$, vitamin $\mathrm{C}$ and $B$ (Jukanti et al.). Every seed is a potential harbor of a wide variety of mycoflora containing both pathogenic and saprophytic microorganisms, both externally and internally (Utobo et al. 2011). These mycoflora deteriorate seed quality, affect viability and reduce germination of seeds, resulting in the production of abnormal seedlings (Paul 1989, Bateman and Kwasna 1999, Khanzada et al. 2002). In case of severe fungal infection the seed completely deteriorates and the grain may become unsuitable even for animal consumption due to production of mycotoxic substances by seed fungi.Several fungicides have been recommended for control of seed-borne fungi of pulse crops.

* Corresponding author E-mail: mini_mahal@yahoo.com 
Chemical methods of disease management can affect the beneficial microbial population present in the ecosystem. Natural plant extracts important sources of new agrochemicals and non-selective pesticides for control of plant diseases (Gulter 1988, Tripathi and Dubey 2004). Plant extracts showed antifungal activity against a wide range of fungi (Masoko et al. 2007, Abd-Alla et al. 2001). Therefore, the present investigation was conducted in order to find out the effect of fungicides and plant extracts on seed germination and SAM of lentil and Khesari.

\section{Materials and Methods}

\section{Materials used}

The seed samples of lentil and Khesari were collected from Beena Seed Huose, Harogram bazer, Rajshahi, Bangladesh during June - August 2012. The chemical fungicides viz., Captan and Dithane M45 were purchased from Sarker Agrochemical shops at local market in Rajshahi, Bangladesh. Plant materials were collected from Rajshahi University campus and local market in Rajshahi.

\section{Treatment with fungicides}

Fungicides viz., Captan $\{\mathrm{N}$-(trichloromethylthio) cyclohex-4-ene-1,2-dicarboximide $\}$ and Dithane M-45 (Manganese ethylene bisdithio carbamate plus zinc) were prepared @ 0.3, 0.5, 0.7, 0.9, 1.0 and 1.2, $1.4 \%$ on the basis of the seed weight. Twenty gram of seeds was taken in $250 \mathrm{ml}$ conical flask and $50 \mathrm{ml}$ of each percentage of fungicide was added separately. The flasks were then shaken properly and kept for 30 minutes. After that the treated seeds were soaked with blotting paper. Then fungicides treated these seeds were applied for blotter test to determine seed germination and SAM.

\section{Preparation of plant extracts and treatment}

Plant materials fresh leaves of Azadirachta indica (neem), clove of Allium sativum (garlic) and rhizome of Gingiber officinale (ginger) were thoroughly washed in tap water. Fifty gram of each plant material were mixed with distilled water (w/v 1:1) and crushed thoroughly in a mortar with pestle and then passed through two layers of cheese cloth (Hossain et. al. 1997). The extracts were centrifuged at $3000 \mathrm{rpm}$ for 20 minutes and stored in a refrigerator at $4^{\circ} \mathrm{C}$ until used. Seeds were treated with the prepared plant extracts separately by dipping method for 30 minutes. The treated seeds were soaked on blotting paper and placed on moist blotter to determine seed germination and SAM.

\section{Detection of fungi and seed germination percentage on blotter test method}

The detection of seed mycoflora and seed germination was carried out by the blotter test as recommended by the International Seed Testing Association (ISTA-1966) with some modifications (Basak and Mridha 1985, Basak et al.1991). Blotting papers were soaked in sterile distilled water and three layers were placed in each Petri dish. One hundred seeds were taken at random as per ISTA rules. Out of 100 seeds, 25 seeds per petridish in case of mungbean and 10 seeds in case of chickpea were placed. The petridishes were then incubated at $28 \pm 2^{\circ} \mathrm{C}$ under defused light for seven days. Treated and control seeds were evaluated for recording percentage of seed germination with the following the formula

Germination $(\%)=($ Number of seeds germinated/Total number of seeds used $) \times 100$

After seven days of incubation, the plated seeds were examined under a stereoscopic binocular microscope for the observation of fungi. The emerging fungi on blotter were subcultures on PDA plate for identification following the keys outlined by Gilman 1957, Booth 1971, Subramanian 1971, Ellis 1971 and Alexopoulos \& Mims 1979. 


\section{Statistical analysis of data}

A completely randomized design was used for evaluating and interpreting the results, the collected data were analyzed following biometrical technique developed by Mather (1949) and Allard (1960) based on the mathematical models of Fisher et al. (1932). Analysis of the variance (ANOVA) was done accordingly and the test of significance was done by least significant differences (LSD) test at $5 \%$ level.

\section{Results}

\section{Effect of fungicides on seed germination and reduction of SAM}

Seed germination of both lentil and Khesari were highly influenced by the fungicide used. Seed germination was also affected with the fungicide types and doses (Table 1). In lentil, the seed germination was the highest (98 and 95\%) when treated with 1.2 and 1.4\% doses of captan and dithane-M 45, respectively and the lowest were 89 and $91 \%$ at $0.3 \%$ dose of both tested fungicides. In both treatments the seed germination was increased up to $20 \%$ over control. In case of Khesari, the seed germination was the maximum (96 and $95 \%$ ) when treated with 1.2 and 1.4\%, captan and dithane-M 45, respectively and the minimum were 85 and $89 \%$ at $0.3 \%$ dose of tested fungicides. In both treatments the seed germination was increased by 17.28 and $18.75 \%$ over control when treated with 1.2 and $1.4 \%$, captan and dithane-M 45 , respectively. Captan was most effective than dithane-M 45 to increased seed germination percentage of both pulses (Table 1).

Seed associated mycoflora (SAM) of lentil and khesari was remarkably reduced by the fungicide used. SAM was also controlled with the fungicide types and doses (Table 2 and 3). In blotter test isolated fungi were identified as Aspergillus flavus, Fusarium oxysporum and Penicillium sp. in lentil and in case of khesari seeds, it was A. flavus, F. oxysporum, Penicillium sp. and Macrophomina phaseolina. (Fig.1.).
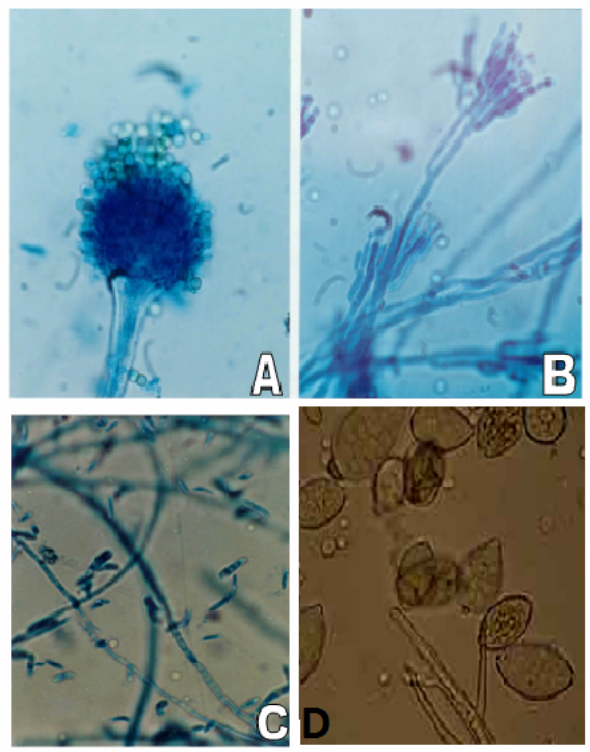

Fig. 1. A. Aspergillus flavus B. Penecillium sp. C. Fusarium oxysporum and D. Macrophomina phaseolina which are recovered from lentil and khesari seeds. 
Among them A. flavus (9, 15 and 19\%). and $F$. oxysporum (12, 16 and 20\%) were the most dominant fungi in lentil and khesari, respectively for both treatments and control. Both the fungicides remarkably reduced the number of mycoflora of the seeds of lentil and Khesari (Table 2 and 3). It was observed that $1.2 \%$ of captan and $1.4 \%$ of dithane $\mathrm{M}-45$ completely controlled all fungi from the seeds of lentil and khesari and $0.3 \%$ dose of both the fungicides was less effective. A. flavus and F. oxysporum were completely controlled at $1.2 \%$ of captan and $1.4 \%$ of dithane M-45 treated lentil and Khesari seeds whereas it was $1.0 \%$ and $1.4 \%$ for Penicillium sp.. Macrophomina phaseolina was also totally controlled at $1.0 \%$ of captan and $1.2 \%$ of dithane M-45 in khesari. (Fig. 2.)
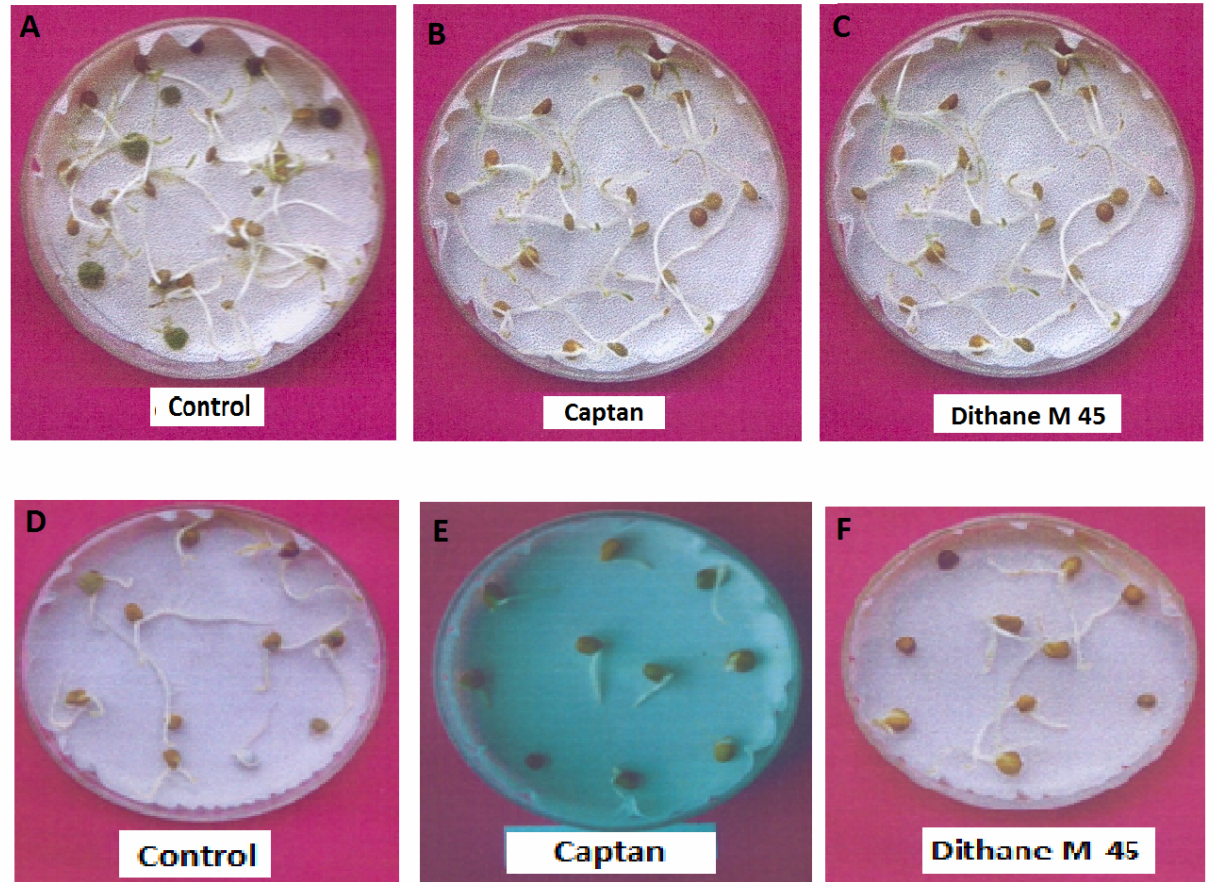

Fig. 2. A and D. Infected lentil and khesari seeds in control; $B$ \& $C$ and $E \&$ F complete elimination of seed mycoflora with Captan and Dithane M-45.

\section{Effect of plant extracts on seed germination and SAM}

Seed germination of both lentil and khesari were highly influenced by the different aqueous plant extracts used (Table 1). In lentil, the seed germination was maximum (94\%) when treated with Azadirachta indica leaf extract and germination increased by $16 \%$ over control whereas the minimum was recorded $88 \%$ with Zingiber officinale extract (Table 1). In case of Khesari, the seed germination was the highest (94\%) when treated with Azadirachta indica leaf extract and it increased by $17.50 \%$ over control. The lowest seed germination was found $85 \%$ with $A$. sativum extract. $A$. indica showed best effect than other tested plant extracts to increased seed germination percentage of both pulses (Table 1). 
Plant extracts also showed antifungal activity in controlling of SAM of both pulses (Table 2 and 3). In lentil seeds, A. flavus was successfully controlled with all tested plant extracts and $A$. sativum also totally controlled $F$. oxysporum (Table 2). Among other fungi partially reduced over control. In case of khesari, $A$. flavus was completely controlled with all tested plant extracts and $F$. oxysporum was also totally controlled with A. sativum extract (Table 3).

Table 1. Effect of fungicides and plant extracts on seed germination of lentil and khesari seeds in blotter test after 7 days of incubation at $28 \pm 2^{\circ} \mathrm{C}$.

\begin{tabular}{|c|c|c|c|c|c|}
\hline \multirow[t]{2}{*}{ Treatment } & \multirow[t]{2}{*}{ Dose (\%) } & \multicolumn{2}{|c|}{ Seed germination (\%) } & \multicolumn{2}{|c|}{$\begin{array}{l}\text { Germination increase (\%) over } \\
\text { control }\end{array}$} \\
\hline & & Lentil & Khesari & Lentil & Khesari \\
\hline \multirow{6}{*}{ Captan } & 0.3 & 89 & 91 & 09.88 & 13.75 \\
\hline & 0.5 & 90 & 92 & 11.11 & 15.00 \\
\hline & 0.7 & 93 & 94 & 14.81 & 17.50 \\
\hline & 0.9 & 94 & 95 & 16.05 & 18.75 \\
\hline & 1.0 & 96 & 96 & 18.52 & 20.00 \\
\hline & 1.2 & 98 & 96 & 20.99 & 20.00 \\
\hline F value $\left(L^{2} D_{p \leq 0.05}\right)$ & \multicolumn{3}{|l|}{$13.35(1.58)^{\star}$} & \multicolumn{2}{|l|}{$13.86(1.92)^{\star}$} \\
\hline \multirow{7}{*}{ Dithane-45 } & 0.3 & 85 & 89 & 04.94 & 11.25 \\
\hline & 0.5 & 87 & 89 & 07.41 & 11.25 \\
\hline & 0.7 & 88 & 90 & 08.64 & 12.50 \\
\hline & 0.9 & 90 & 91 & 11.11 & 13.75 \\
\hline & 1.0 & 91 & 93 & 12.35 & 16.25 \\
\hline & 1.2 & 94 & 95 & 16.05 & 18.75 \\
\hline & 1.4 & 95 & 95 & 17.28 & 18.75 \\
\hline F value $\left(L^{\prime} S D_{p \leq 0.05}\right)$ & \multicolumn{3}{|l|}{$24.76(1.16)^{\star}$} & \multicolumn{2}{|l|}{$26.05(1.40)^{\star}$} \\
\hline \multicolumn{6}{|l|}{ Plant extracts } \\
\hline Azadirachta indica & $1: 1$ & 94 & 94 & 16.05 & 17.50 \\
\hline Zingiber officinale & $1: 1$ & 88 & 88 & 08.64 & 10.00 \\
\hline Allium sativum & $1: 1$ & 90 & 85 & 11.11 & 06.25 \\
\hline F value $\left(\operatorname{LSD}_{p \leq 0.05}\right)$ & \multicolumn{3}{|l|}{$6.28(7.17)^{\star}$} & & \\
\hline Control & & 81 & 80 & & \\
\hline
\end{tabular}

$\mathrm{a}=$ Mean of three replications. * = Significant at 5\% level. 
Table 2. Effects of fungicides and plant extracts in controlling SAM of lentil seed in blotter test after 7 days of incubation at $28 \pm 2^{\circ} \mathrm{C}$.

\begin{tabular}{|c|c|c|c|c|}
\hline \multirow[t]{2}{*}{ Treatment } & \multirow[t]{2}{*}{ Dose $(\%)$} & \multicolumn{3}{|c|}{ Incidence of seed associated fungi a (\%) } \\
\hline & & $\begin{array}{c}\text { Aspergillus } \\
\text { Flavus }\end{array}$ & $\begin{array}{l}\text { Fusarium } \\
\text { oxysporum }\end{array}$ & Penicillium sp. \\
\hline \multirow{6}{*}{ Captan } & 0.3 & 9 & 7 & 8 \\
\hline & 0.5 & 7 & 6 & 7 \\
\hline & 0.7 & 5 & 3 & 5 \\
\hline & 0.9 & 4 & 2 & 4 \\
\hline & 1.0 & 2 & 2 & 0 \\
\hline & 1.2 & 0 & 0 & 0 \\
\hline$F$ value $\left(L S D_{p \leq 0.05}\right)$ & \multicolumn{4}{|l|}{$42.80(1.04)^{\star}$} \\
\hline \multirow{7}{*}{ Dithane-45 } & 0.3 & 15 & 8 & 12 \\
\hline & 0.5 & 11 & 5 & 10 \\
\hline & 0.7 & 10 & 4 & 7 \\
\hline & 0.9 & 8 & 3 & 4 \\
\hline & 1.0 & 3 & 3 & 3 \\
\hline & 1.2 & 1 & 2 & 1 \\
\hline & 1.4 & 0 & 0 & 0 \\
\hline$F$ value $\left(\operatorname{LSD}_{p \leq 0.05}\right)$ & \multicolumn{4}{|l|}{$15.52(2.13)^{\star}$} \\
\hline \multicolumn{5}{|l|}{ Plant extracts } \\
\hline Azadirachta indica & $1: 1$ & 0 & 2 & 4 \\
\hline Zingiber officinale & $1: 1$ & 0 & 2 & 1 \\
\hline Allium sativum & $1: 1$ & 0 & 0 & 3 \\
\hline F value $\left(L^{2} D_{p \leq 0.05}\right)$ & \multicolumn{4}{|l|}{$0.75(2.62)^{*}$} \\
\hline Control & & 19 & 10 & 15 \\
\hline
\end{tabular}

a =Mean of three replications. ${ }^{*}=$ Significant at $5 \%$ level. 
Table 3. Effects of fungicides and plant extracts in controlling SAM of khesari seed in blotter test after 7 days of incubation at $28 \pm 2^{\circ} \mathrm{C}$

\begin{tabular}{|c|c|c|c|c|c|}
\hline \multirow[t]{2}{*}{ Treatment } & \multirow[t]{2}{*}{ Dose (\%) } & \multicolumn{4}{|c|}{ Incidence of seed associated fungia $(\%)$} \\
\hline & & $\begin{array}{c}\text { Aspergillus } \\
\text { Flavus }\end{array}$ & $\begin{array}{l}\text { Fusarium } \\
\text { oxysporum }\end{array}$ & Penicillium sp. & $\begin{array}{c}\text { Macrophomina } \\
\text { phaseolina }\end{array}$ \\
\hline \multirow{6}{*}{ Captan } & 0.3 & 11 & 12 & 9 & 5 \\
\hline & 0.5 & 9 & 9 & 6 & 4 \\
\hline & 0.7 & 5 & 4 & 4 & 2 \\
\hline & 0.9 & 3 & 2 & 2 & 0 \\
\hline & 1.0 & 1 & 1 & 0 & 0 \\
\hline & 1.2 & 0 & 0 & 0 & 0 \\
\hline$F$ value $\left(L S D_{p \leq 0.05}\right)$ & \multicolumn{5}{|l|}{$36.55(1.52)^{*}$} \\
\hline \multirow{7}{*}{ Dithane-45 } & 0.3 & 14 & 16 & 10 & 8 \\
\hline & 0.5 & 12 & 12 & 7 & 5 \\
\hline & 0.7 & 8 & 8 & 7 & 3 \\
\hline & 0.9 & 8 & 5 & 4 & 2 \\
\hline & 1.0 & 4 & 5 & 2 & 2 \\
\hline & 1.2 & 1 & 2 & 2 & 0 \\
\hline & 1.4 & 0 & 0 & 0 & 0 \\
\hline$F$ value $\left(L^{2 S D_{p} \leq 0.05}\right)$ & \multicolumn{5}{|l|}{$27.91(1.81)^{\star}$} \\
\hline \multicolumn{6}{|l|}{ Plant extracts } \\
\hline Azadirachta indica & $1: 1$ & 0 & 3 & 3 & 7 \\
\hline Zingiber officinale & $1: 1$ & 0 & 5 & 2 & 5 \\
\hline Allium sativum & $1: 1$ & 0 & 0 & 4 & 6 \\
\hline F value $\left(L^{2} D_{p \leq 0.05}\right)$ & \multicolumn{5}{|l|}{$3.67(2.07)^{\star}$} \\
\hline Control & & 17 & 20 & 14 & 9 \\
\hline
\end{tabular}

a =Mean of three replications. ${ }^{*}=$ Significant at $5 \%$ level.

\section{Discussion}

\section{Effect of fungicides on seed germination and reduction of SAM:}

The highest seed germination percentage of lentil seeds were recorded 98 and $95 \%$ when treated with 1.2 and $1.4 \%$ doses of captan and dithane-M 45, respectively and the lowest were 89 and $91 \%$ at $0.3 \%$ dose of both tested fungicides. In both treatments the seed germination was increased up to $20 \%$ over control. In case of Khesari, the seed germination was the maximum (96 and 95\%) when treated with 1.2 and $1.4 \%$, captan and dithane-M 45 , respectively and the minimum were 85 and $89 \%$ at $0.3 \%$ dose of tested fungicides. In both treatments the seed germination was increased by 17.28 and $18.75 \%$ over control when treated with 1.2 and $1.4 \%$, captan and dithane-M 45, respectively. Captan was most effective than dithane-M 45 to 
increased seed germination percentage of both pulses (Table 1). This result is in conformity with the findings of Umesh and Maske (2012) who observed that benomyl, dithane M-45 and bavistin effectively increased the germination percentage of cowpea. In another study De and Chaudhury (1999) reported that bavistin, mancozeb M-45 and vitavax treated seeds of lentil enhanced the germination compared to control. These findings completely agree with the present observation.

In blotter test isolated fungi were identified as Aspergillus flavus, Fusarium oxysporum and Penicillium sp. in lentil and in case of khesari seeds, it was A. flavus, F. oxysporum, Penicillium sp. and Macrophomina phaseolina (Table 2 and 3). Among them A. flavus (9, 15 and 19\%). and $F$. oxysporum (12, 16 and 20\%) were the most dominant fungi in lentil and khesari respectively for both treatments and control. It was observed that $1.2 \%$ of captan and $1.4 \%$ of dithane M- 45 completely controlled all fungi from the seeds of lentil and khesari and $0.3 \%$ dose of both the fungicides was less effective. A. flavus and $F$. oxysporum were completely controlled at $1.2 \%$ of captan and $1.4 \%$ of dithane M- 45 treated lentil and khesari seeds whereas it was $1.0 \%$ and $1.4 \%$ for Penicillium sp.. Macrophomina phaseolina was also totally controlled at $1.0 \%$ of captan and $1.2 \%$ of dithane M-45 in khesari. In similar observation, Singh et al. (2002) reported that Captan, Dithane M-45, Vitavax, Bavistin were effective in controlling of Fusarium sp. on mungbean.

\section{Effect of plant extracts on seed germination and SAM:}

In case of lentil, the maximum seed germination (94\%) was observed with $A$. indica leaf extract treated seeds and it increased germination by $16 \%$ over control (Table 1). This is in agreement with the findings of Ahmed et al. (2013) who found $A$. sativum extract was superior in terms of increasing germination of rice seeds to other extracts followed by A. indica, Polygonum hydropiper (bishkatali), Allamanda cathartica and Swertia. In khesari, the highest germination (94\%) was found when the seeds were treated with $A$. indica extract and it increases germination (17.5\%) over control. In similar study, Mondall et al., (2009) reported that seed treatment with the $A$. sativum extract and neem, gagra, vatpata and bishkatali leaf extracts increased germination percentage of wheat seeds and among them garlic and neem bark gave better results.

In lentil seed, A. flavus was successfully controlled with all tested plant extracts and $A$. sativum also totally controlled F. oxysporum (Table 2). Among other fungi partially reduced over control. In case of khesari, $A$. flavus was completely controlled with all tested plant extracts and $F$. oxysporum was also totally controlled with $A$. sativum extract (Table 3). In similar investigation, Suratuzzama et al. (1995) observed that $Z$. officinale extract showed good effect in controlling of Pyricularia oryzae and Curvularia lunata. Hasan et al. (2005) found that the extracts of garlic bulb, neem and nayantara leaf were more effective for reduction the incidence of seeds borne fungi of wheat.

Thus, the present study highlight the importance of seed treatment with most effective fungicides and plant extracts in controlling of mycoflora of lentil and khesari seeds. It was observed that seed treated with the fungicides effectively increased seed germination and controlled the seed associated mycoflora but it was not ecofriendly, polluted our environment. A. sativum showed promising result in controlling of seed mycoflora of pulses. So this extract can be used in controlling of seed mycoflora instead of chemical fungicides for safe environment. 


\section{References}

Abd-Alla M S, Atalla K M, El-Sawi M A M. 2001. Effect of some plant waste extracts on growth and aflatoxin production by Aspergillus flavas. Annals Agric Sci 46, 579-592.

Ahmed M, Hossain M, Hassan K, Dash C K. 2013. Efficacy of different plant extract onreducing seed borne infection and increasing germination of collected rice seed sample. Universal J of Plant Sci 1(3), 66-73.

Alexopoulos, C J, Mims C W. 1979. Introductory Mycolpogy. $3^{\text {rd }}$ Ed. John Willey and Sons. Inc., U.S.A.

Allard R W. 1960. Principles of the plant Breeding. John Wiley and Sons. Inc.N.Y.

Bateman G L, Kwasna H. 1999. Effects of number of winter wheat crops grown successively on fungal communities on wheat roots. Appl Soil Ecol 13, 271-282. http://dx.doi.org/10.1016/S0929-1393(99)00040-2

Basak A B, Mridha M A U. 1985 Mycoflora associated with seeds of different varieties Aman rice collected from Chittagong and Chittagong Hill-tract districts of Bangladesh. Seed res 13 (2), 78-84.

Basak A B, Mridha M A U, Fakir G A. 1991. Mycoflora of Chilli seed as isolated from different types of fruit rot occurring in Chittagong district. Chittagong Univ stud Part II 15 (2), 11-17.

Booth C. 1971. The Genus Fusarium. Commonwealth Mycological Institute. Kew, Surrey, England.

De K R, Chaudhary R G. 1999. Biological and chemical seed treatment against lentil wilt. LENS Newsletters 26, 725729

Ellis M B. 1971. Dematiatiaceous Hypomycetes. Commonwealth Mycological Institutes. Kew, Surrey, England.

Fisher R A, Immer F R, Tedin O. 1932. The genetical interpretation of statistics of the third degree in the study of quantitative inheritance. Genetics 17,107-124.

Gillman J C. 1957. A Manual of soil fungi. Lowa State Univ. Press.

Gulter H C. 1988. Natural products and their potential in agriculture: In Gulter, H.C. (Ed.) Biologically active natural products: Potential use agriculture. American Chemical Soc, Washington, pp.1-2.

Hasan M M, Chowdhury S P, Alam S, Hossain B, Alam M S. 2005. Antifungal effect of plant extracts on seed-borne fungi of wheat seeds regarding seed germination, seedling health and vigour index. Pakistan J Bio Sci 8 (9), 1284-1289. http://dx.doi.org/10.3923/pibs.2005.1284.1289

Hossain I, Mahamud H, Ashrafuzzaman H. 1997. Effect of plant extracts on fungi (Bipolaris sorokiniana and Rhizoctonia solani) and okra mosaic disease. Ecoprint 4(1), 35-42

ISTA (1966) International Seed Testing Association. Proc. Ins Seed Test. Ass. 1,152

Jukanti A K, Gaur PM, Gowda C L L, Chibbar R N. 2012. Nutritional quality and health benefits of chickpea (Cicer arietinum L.). Br J Nutr 108, 512-526. http://dx.doi.org/10.1017/S0007114512000797, PMid:22916806

Khanzada K A, Rajput M A, Shah G S, Lodhi A M, Mehboob F. 2002. Effect of seed dressing fungicides for the control of seed borne mycota of wheat. Asian J of Plant Sci 1, 441-444. http://dx.doi.org/10.3923/ajps.2002.441.444

Mather K. 1949. Biometrical genetics. Dover, Pub.Inc. Newyork.

Mondall N K, Mojumdar A S K, Chatterje A, Banerjee J K, Gupta S. 2009. Antifungal activities and chemical characterization of neem leaf extracts on the growth of some selected fungal species in vitro culture medium. $\mathrm{J}$ of Appl Sci and Environ Management 13(1), 49-53.

Masoko J, Picard J N, Eloff P. 2007. The antifungal activity of twenty-four southern African Comretum species (Combretaceae). South Afr J Bot 73, 173-183. http://dx.doi.org/10.1016/j.sajb.2006.09.010 
Paul Y S. 1989. Seed borne mycota of soybean and its control in Himachal Prodesh. Indian J of Mycol and Plant Pathol119, 235-257.

Singh S D, Rawal P, Shekawat N S, Lodha P C. 2002. Management of mungbean (Vigna radiate L Wikzek) seed mycoflora by seed dressing fungicides. J Mycol Plant Pathol 23(1), 149.

Subramanian C V. 1971. Hypomycetes. Indian Council of Agricultural Research, New Delhi.

Suratuzzaman M, Hossainand I, Fakir G A. 1995. Study on seed borne fungi of soyabean and its control. M. Sc. Ag. Thesis. Dept. of PI. Pathol. BAU, Mymensingh, Bangladesh, pp. 58

Tripathi P, Dubey N K. 2004. Exploitation of natural products as an alternative strategy to control post harvest fungal rotting of fruit and vegetables. Post harvest Bio and Technol 32, 235-245.

Umesh P M, Sanjay R M. 2012. Efficacy of bioagents and fungicides on seed mycoflora, germination and vigour index of cowpea. Sci Res Reporter 2(3), 321-326.

Utobo E B, Ogbodo E N, Nwogbaga A C. 2011. Seed borne mycota associated with rice and their influence on growth of Abakaliki, Southeast agro-ecology, Nigeria. Libiyan Agric Res Cen J Inter 2, 79-84. 